\title{
DAMOCLES
}

- EU-kommissionens bidrag til IPY

Af Rasmus Tonboe, Søren Andersen og Torben Schmith, DMI

De danske forskningsbevilligende myndigheder har i modsætning til en række andre lande indtil videre vist en påfaldende tilbageholdenhed i forbindelse med Det Internationale Polarår (IPY). Og det haster - IPY løber fra marts 2007- marts 2009.

EU kommissionen har derimod fastlagt planerne for IPY, og kommissionens bidrag til IPY under det 6 . rammeprogram bliver det netop igangsatte $16 \mathrm{M} €$ integrerede projekt DAMOCLES (2006-2011) med dansk deltagelse fra DMI (Danmarks Meteorologiske Institut), DNSC (Det Danske Rumcenter) og DTU (Danmarks Tekniske Universitet).

\section{IPY's historie}

Siden det første polarår (1882-1883) har polarforskere med ca. 50 års mellemrum koordineret deres indsats for at opnå et sammenhængende billede af polarområdernes tilstand og primært - geofysiske processer. Vi står nu foran det fjerde polarår, IPY.

Det første polarår 1882-1883 med deltagelse af 12 lande i Nordamerika og Nordeuropa koordinerede ekspeditioner, etablerede internationalt samarbejde og foretog systematiske målinger i løbet af polaråret ved 13 meteorologiske stationer specielt i Arktis. Det dengang nyligt oprettede Meteorologiske Institut (grundlagt i 1872) repræsenterede Danmark og stod for magnetiske og meteorologiske målinger i Godthåb/Nuuk. I Andree's Handatlas fra 1881 er områderne nord for $80^{\circ} \mathrm{N}$ og syd for $70^{\circ} \mathrm{S}$, hvide, altså ikke tilstrækkeligt kortlagt og geografisk opdagelse var en væsentlig del af formålet med det første polarår.

Det andet polarår 1930-1932 blev koordineret af den Internationale Meteorologiske Organisation og havde deltagelse fra 40 lande. Den internationale polarårs-kommission blev ledet af direktøren for Meteorologisk Institut Dan la Cour. Dette polarår fokuserede specielt på meteorologiske og magnetiske målinger og processer fx jetstrømmen, og der blev etableret 40 permanente målestationer. På det tidspunkt var der 15 danske vejrstationer på Grønland (samt 5 norske og 1 amerikansk).

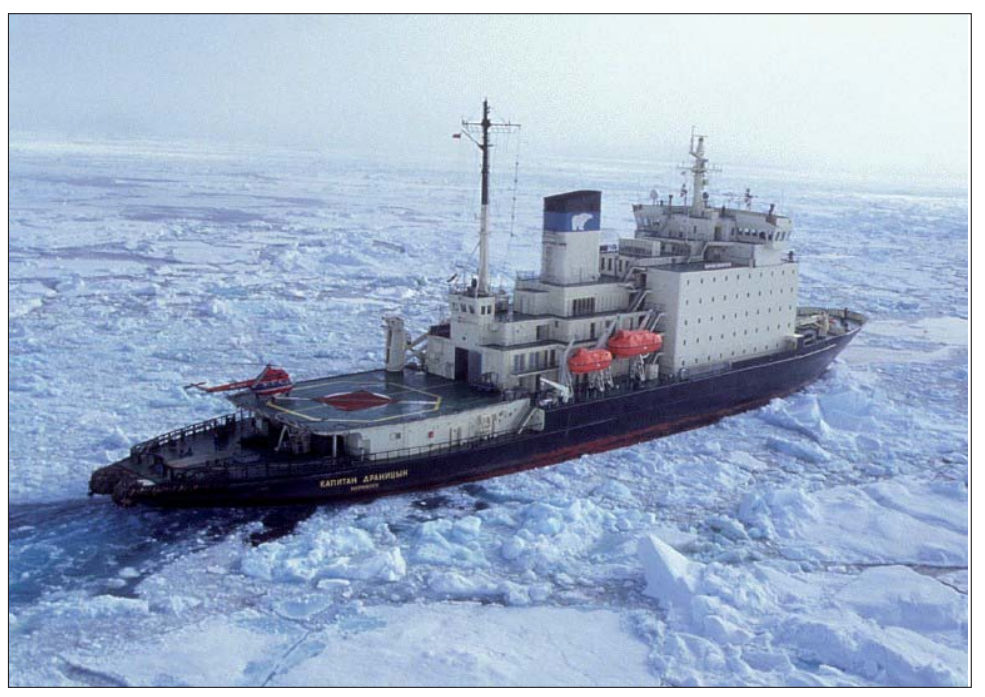

Russiske isbrydere skal så vidt muligt hjœlpe Tara frem til den ønskede fastfrysningsposition. (Foto: Murmansk Shipping Company)

Meteorologisk Institut foretog allerede dengang systematiske magnetiske målinger i Godhavn/Qeqertarsuaq og var internationalt anerkendt for dette arbejde. Det er en position og tradition der fortsættes på DMI $i$ dag, fx i forbindelse med Ørsted-satellitten.

I det Internationale Geofysiske År (IGY) 1957-1958, som samtidig var det tredje polarår, ønskede man at anvende den teknologiske udvikling, der var foregået under og efter anden verdenskrig til at fremme geofysisk forskning. Specielt raket- og radar-teknologi og udforskningen af den ydre atmosfære og rummet med opsendelsen af de første satellitter (Sputnik-1 og Sputnik-2 med hunden Laika ombord, 1957, Explorer1 og Sputnik-3, 1958). Den amerikanske Explorer-1 detekterede Van Allen bælterne. Ionosfæren og magnetiske målinger var igen et vigtigt element i Danmarks og DMIs indsats. Andre vigtige geofysiske resultater i IGY var kortlægning af Antarktis' iskappe. Desuden kortlægning af oceanbundsspredningszoner og dermed underbygning af Alfred Wegeners kontinentaldriftsteori.

\section{IPY 2007-2008}

Defineret bredt vil det næste polarår udnytte de seneste 50 års teknologiske udvikling specielt satellitkortlægning og automatiske observationssystemer til at forbedre de modeller, der beskriver vores klima. Klimaændringer forstærkes i polarområder, og man ønsker at beskrive og forudse konsekvenserne også globalt. Det er vigtigt at IPY efterlader sig en observationsinfrastruktur, der vil blive til gavn i fremtiden. Desuden ønsker man at udbrede kendskabet i offentligheden og den videnskabelige verden til processer i polarområderne og deres betydning. Der er fra FNs side kun begrænsede midler til afholdelsen af IPY-aktiviteter, og disse retter sig primært mod koordination. Med undta- 


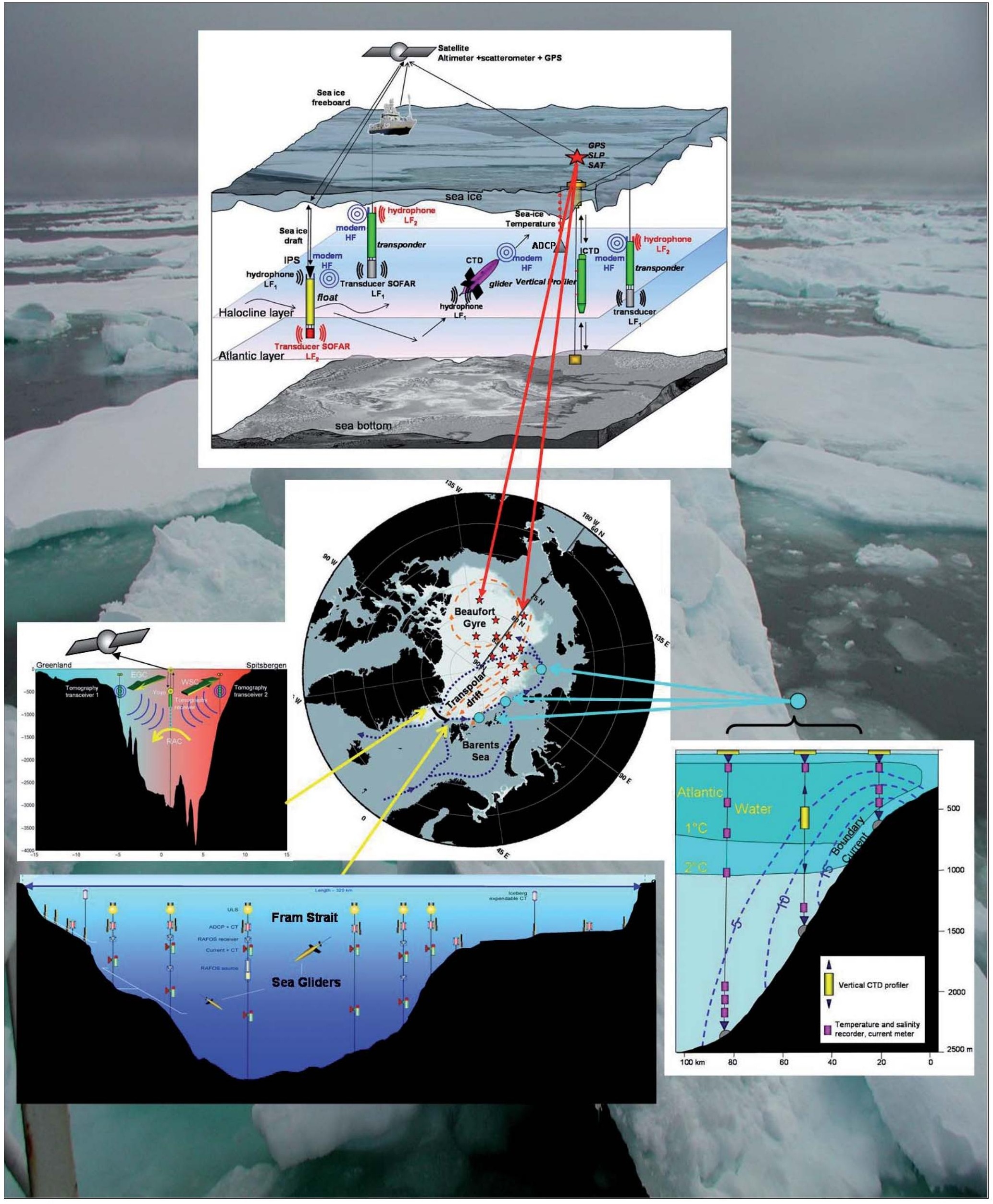

Måleprogrammet i DAMOCLES inkluderer fly-og satellittelemåling, konventionelle in situ målinger af sne is og meteorologi samt oceanografiske målinger. (Grafik: DAMOCLES) 
Tara inspireret af Nansens Fram (18931896) og de russiske driftstationer (1937- ) fryses ind i isen i det østlige Sibirien og transporteres med den transpolcre isdrift mod Framstrcedet. (Foto: Tara Expeditions)

gelse af EU-kommissionens bidrag skal IPY i Europa primært finansieres nationalt, og mange konsortier bliver uden tvivl reduceret i denne proces.

\section{DAMOCLES}

Tykkelsen af den arktiske havis viser markante reduktioner i løbet af 1990'erne og satellitdata viser, at flerårsisen gradvist bliver erstattet af nyis og vinteris. Igennem specielle feedback-mekanismer forstærkes effekten af global opvarmning i Arktis, hvilket samtidigt øger vigtigheden af denne region i det globale klimabudget.

Modeller, der integrerer vores viden, viser, at selv små ændringer i energifluksen til det Arktiske Ocean kan have en betydelig indflydelse på havisen. Det Arktiske Ocean og havisen er derfor et godt sted at holde øje, hvis man vil have tidlige advarsler om klimaændringer. Desværre er samspillet mellem atmosfæren og det Arktiske Ocean kun kortlagt i grove træk. Der er derfor ingen tvivl om, at et mere omfattende observationsnet kombineret med modelstudier er presserende.

DAMOCLES: Developing Arctic Modelling and Observation Capabilities for Long-term Environmental Studies er et svar på dette behov.

EU kommissionen 6. rammeprogram støtter store projekter, og DAMOCLES er da også det største Arktiske EU-forskningsprojekt nogensinde med 45 partnere fra 12 europæiske lande. Det er samtidig kommissionens bidrag til IPY. DAMOCLES, der ledes af Professor Jean-Claude Gascard fra Pierre og Marie Curie Universitet i Paris, handler om at kortlægge fysiske processer i og omkring det Arktiske Ocean, forbedre modeller og reducere usikkerheden på klimaprognoser. Dette gøres bl.a. ved at anlægge et omfattende observationssystem og desuden forsøge at besvare følgende 8 spørgsmål:

1) Er det arktiske system på overgangen til en ny ligevægt?

2) Er det arktiske klima virkelig så følsomt over for globale ændringer, som modellerne viser, og hvordan kan man så bruge det arktiske system som et mål for ændringer?

3) Hvor langt vil havisen trække sig tilbage i fremtiden?

4) Hvad bliver konsekvenserne af mindre havis?

5) Hvad er sammenhængen mellem det arktiske og det globale system?

6) I hvilken grad skyldes ændringer menneskets indvirken?

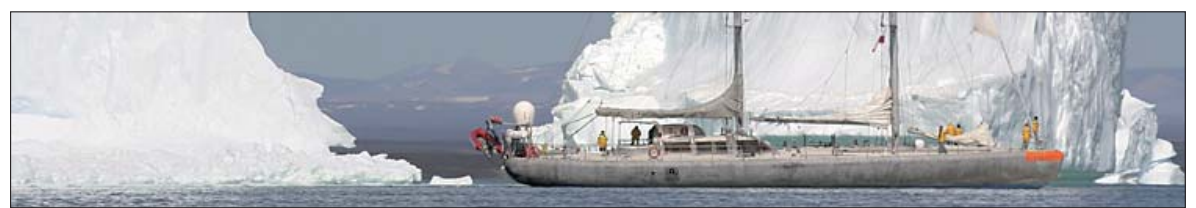

7) Hvilke processer er mest relevante, og er disse beskrevet ordentligt i modeller?

8) Hvordan opstiller man et arktisk observationssystem?

\section{Formålet}

DAMOCLES formål er direkte forenelige med den arktiske og geofysiske del af IPY, og projektet har tætte forbindelser til blandt andet det amerikanske SEARCH program og NABOS med deltagelse af USA, Rusland og Canada samt aktiviteterne omkring de russiske driftstationer, der har fungeret siden 1937

Der er tre danske partnere i DAMOCLES, nemlig DMI, DTU og DNSC, som hovedsageligt vil beskæftige sig med telemåling af havis.

DMI vil stå for udviklingen af teoretiske mikrobølgestrålingsmodeller for havis og sneen ovenpå. Disse modeller er vigtige for at kunne "oversætte" satellitmålinger til havisens fysiske egenskaber. Potentielt kan strålingsmodellerne også bruges til at udnytte satellitdata i vejrmodeller bedre. En kor- rekt beskrivelse af den Arktiske atmosfæres vanddamp- og temperaturforhold kan have betydning for vejrprognosekvaliteten langt ned i Europa. DMI er desuden, ligesom DTU, involveret $i$ at kortlægge havisens bevægelsesmønstre med satellit, og DTU er involveret $i$ at kortlægge den Arktiske atmosfære med satellit.

Isens målte bevægelsesmønstre er vigtige assimileringsdata $i$ havismodeller og spiller en vigtig rolle i forståelsen af samspillet mellem atmosfæren og det Arktiske Ocean. DNSC kortlægger havisens overfladehøjde med fly-bårent altimeter. Det var oprindeligt tanken, at disse målinger skulle kombineres med tilsvarende målinger fra CryoSat. Desværre gik CryoSat tabt, da et raketmodul fejlede under opsendelsen i oktober 2005 (se GN 5/05). CryoSat-2, med planlagt opsendelse om tre år, kan dog stadig nå at blive en del af projektet.

Ud over de videnskabelige udfordringer ligger der de næste 5 år et stort arbejde med at koordinere og samle de forskellige aktiviteter i DAMOCLES internt og med IPY. 